\title{
Lingkungan Sosial Media Mempengaruhi Kesuksesan Sebuah Branding Melalui Komunitas Public Figure
}

\author{
Felicia Canesta,Efendi, dan Kelvin \\ Universitas Internasional Batam \\ 1831087.felicia@uib.edu
}

\begin{abstract}
ABSTRAK
Media sosial memperkenalkan beberapa perubahan penting pada pemasaran digital. Perkembangan teknologi memfasilitasi peningkatan keterhubungan dan pemberdayaan pengguna media sosial saat ini. $\mathrm{Hal}$ ini mendorong perkembangan pemasaran branding melalui komunitas online di lingkungan media sosial, tempat pengguna untuk berpartisipasi dalam pembuatan dan kolaborasi dalam berbagi nilai terhadap produk yang dipasarkan. Komunitas online paling berpengaruh di media sosial memiliki kredibilitas tinggi, dan sejumlah besar koneksi yang diberdayakan mempengaruhi perkembangan aktual perusahaan / pemilik brand, sehingga komunitas online itulah yang diidentifikasi sebagai Influencer atau Public Figure di media sosial. Pemilik brand harus memiliki nilai-nilai atau ide kreatif terhadap produk yang dipasarkan dan harus menyediakan uang yang cukup sebagai bayaran yang harus dilakukan berdasarkan tarif yang ditawarkan oleh komunitas Influencer untuk mempromosikan brand tersebut. Studi penelitian ini bertujuan untuk menganalisis dan menyelidiki dampak perkembangan branding pada ekuitas media sosial yang dilibatkan oleh komunitas Influencer. Hasil pada penelitian ini membuktikan adanya wawasan yang relevan dan dampak yang signifikan dari hasil yang diperoleh praktisi terhadap konsep pengembangan pemasaran digital di lingkungan sosial media yang dilakukan oleh komunitas Influencer.
\end{abstract}

Kata Kunci : Media Sosial, Branding, Influencer, Digital, Pemasaran

\begin{abstract}
Social media introduces several important changes to digital marketing. Technological developments facilitate the current connection and empowerment of social media users. This encourages the development of branding marketing through online communities in the social media environment, where users can participate in the co-creation and collaboration of sharing value on the products being marketed. The most influential online community on social media has high credibility, and a large number of connections could influence the actual development of the company or branding, that's what we called as Influencer or Public Figure in the social media environment. The owner must have a creative values or ideas of their product being marketed and must provide a sufficient money to be paid based on the rates offered by the Influencer Community to promote the brand. This research study aims to analyze and investigate the impact of the development of Branding on the social media equity involved by the Influencer community. The results of this study prove the existence of relevant insights and the significant impact of the results obtained by practitioners on the concept of developing digital marketing in the social media environment carried out by the Influencer community.
\end{abstract}

Keywords : Social Media, Branding, Influencer, Digital, Marketing

\section{PENDAHULUAN}

Branding merupakan aspek penting dalam memulai sebuah usaha. Teori tentang branding pertama kali diperkenalkan dalam pemasaran produk konsumen di tahun 1990-an. Dalam beberapa dekade terakhir, branding telah menjadi semakin populer sebagai alat strategis utama untuk membedakan produk kompetitif. Branding telah memengaruhi cara pemasar memasarkan serta merancang dan membuat konsep sebuah produk. Semakin banyak 
perusahaan atau penjual melakukan riset pasar, termasuk melakukan endorsement melalui Influencers untuk membantu mereka mempromosikan brand miliknya (Cheng, 2015). Tujuan branding ialah untuk memberikan identitas terhadap usaha / produk yang dibangun agar siapapun dapat mengenal sebuah kepemilikan bisnis yang dipasarkan kepada publik. Identitas merek tentunya dapat membantu dalam pengembangan hubungan antara produsen dan konsumen (Gunantara, 2015).

Dibalik itu, media sosial juga menjadi platform utama dalam mengembangkan sebuah Branding. Melalui media sosial, setiap orang yang memiliki akses internet dan dapat menyebar-luaskan pemikiran atau ide, bahan, gambar atau video ke jutaan orang yang memiliki kemungkinan untuk berinteraksi dengannya. Tujuan utama berinteraksi di sosial media menciptakan hubungan pribadi atau bisnis baru (Cakranegara, 2017). Menurut studi DEI Worldwide (2008), $70 \%$ pelanggan telah mengunjungi situs media sosial untuk mendapatkan informasi; $49 \%$ konsumen ini membuat keputusan pembelian berdasarkan informasi yang mereka temukan melalui situs media sosial (Igors, 2014).

Peran seorang Public Figure atau Influencers tentunya juga sangat berpengaruh untuk meningkatkan pemasukan. Konsumen kemungkinan besar mempercayai rekomendasi dari pihak ketiga (Selebgram) terhadap brand itu sendiri. Influencer dapat dianggap sebagai teman yang menghubungkan brand dengan konsumen sebagai targetnya. Influencer tidak hanya membawa pengikut / followers mereka sendiri, tetapi mereka juga membawa jaringan pengikut. Ketika Influencer memiliki pengikut yang loyal, mereka juga dapat mengarahkan hubungan ke situs web perusahaan, meningkatkan paparan media sosial dan menjual produk perusahaan melalui rekomendasi atau kisah mereka tentang pengalamannya dengan produk / layanan tersebut (Karunakaran, 2018).

Berbagai macam bisnis seperti Online Shop sudah menerapkan strategi pemasaran dengan meng-endorse Influencer untuk mempromosikan brand miliknya. Salah satu contohnya seperti brand milik Lady Fame yang berhasil meraih angka hingga lebih dari 110.000 followers di Instagram dalam kurun waktu singkat dan mendapatkan feedback yang memuaskan dari para customer yang berbelanja padanya. Lady Fame Shop menggunakan selebriti endorser sejak akhir 2015 dan selebriti endorser yang digunakan bukan berlatar belakang artis terkenal melalui dunia entertainment melainkan selebgram / selebriti Instagram yaitu Karin Novilda (Suri, 2017).

Hal-hal tersebut tentu dapat dinilai sebagai tolak ukur bahwa kesuksesan sebuah branding dapat dipengaruhi oleh seorang Public figure / Influencer melalui sarana media sosial seperti Instagram, facebook, twitter, maupun youtube. Dalam hal ini, hubungan antar produsen dan Influencer harus memiliki ikatan kepercayaan dan komunikasi yang baik. Produsen juga harus dapat memilih siapa Public Figure / Influencer yang tepat untuk mempromosikan brand miliknya. Terdapat dua faktor yang perlu diperhatikan ketika perusahaan memutuskan untuk memilih Influencer, yaitu; (1) Source Credibility dan (2) Source Attractiveness. Source Credibility merupakan tingkat keahlian dan kepercayaan konsumen pada sumber pesan. Sifat penting dari Source credibility yaitu Expertise (Keahlian) dan Trustworthiness (Kepercayaan). Sedangkan Source Attractiveness merupakan dimensi yang berhubungan dengan penampilan fisik dari selebriti sebagai sumber. Menurut John Dewey, seorang filsuf dari Amerika Serikat dalam bidang pendidikan sosial, menyebutkan bahwa daya tarik fisik merupakan syarat penting dalam individu sebagai penilaian awal orang lain dalam melihat individu tersebut (Goyena, 2019).

Untuk mengoptimalkan kinerja penciptaan bersama di lingkungan media sosial, pemasar harus mengikuti empat langkah berikut: (1) menyiapkan landasan dengan menjelajahi pasar dan kebutuhan pemangku kepentingan; (2) menentukan tren kebutuhan teknologi dan bisnis di pasar; (3) mengidentifikasi pengguna utama (influencer) yang akan secara aktif berpartisipasi dalam kegiatan co-inovasi, dan (4) mengembangkan terobosan dengan terlibat dalam kegiatan kolaboratif dengan kreativitas dalam diri (Igors, 2014). 
Tujuan dari penelitian ini adalah untuk menyoroti pentingnya media sosial pada pemasaran bisnis, menyelidiki konsep keterlibatan merek dan menganalisis peran komunitas influencer dan apakah mereka berdampak pada ekuitas branding dan potensi co-creation di lingkungan media sosial.

Penelitian ini didasarkan pada penelitian yang berkontribusi dalam mengembangkan bidang studi media sosial akademik dan juga sebagai wawasan praktis yang sering kurang dipahami oleh pemasar yang beroperasi di lingkungan media sosial. Penelitian yang menjadi dasar utama pada studi kasus ini adalah penelitian yang dilakukan oleh Wayne D. Hoyer (2010) untuk mengidentifikasi bahwa komunitas Influencers memiliki potensi tertinggi untuk pengembangan produk dan layanan kolaboratif. Hal itu juga mendukung hasil penelitian sebelumnya yang dilakukan oleh Kärkkäinen, Jussila, dan Väisänen (2010).

Penelitian ini mengarah kepada kesimpulan bahwa lingkungan media sosial memiliki fokus yang kuat untuk mengembangkan branding yang dipengaruhi oleh keterlibatan kerja sama antar produsen dan komunitas Influencer dalam menentukan potensi atau dampak pada tingkat penjualan aktual perusahaan (Hoyer, 2010). Menurut Sashi (2012), pemasar harus mengikuti siklus dengan tahapan sebagai berikut: Koneksi; Interaksi; Kepuasan; Penyimpanan; Komitmen; Advokasi; Keterikatan (Chandy, 2010).

Penelitian tersebut juga menarik perhatian praktisi untuk beberapa topik penting mengenai tipologi branding dan media sosial melalui komunitas Influencer yang dirancang oleh Naaman, Boase dan Lai (2010) dan Zhang, Sobei, dan Chowdury (2009). Hal tersebut dibuktikan dari analisis dua perusahaan layanan TI kinerja di Instagram yang menarik untuk dipertimbangkan melalui akun konsumen yang dikembangkan oleh Hanski (2015). la menyatakan Instagram dapat dianggap sebagai sarana media yang kuat. Oleh karena itu untuk membangun koneksi yang bermakna, diperlukan kerja sama antar Influencer dan produsen melalui media sosial. Ini berarti bahwa pemasar juga harus merancang strategi yang terencana untuk merangsang keberlanjutan pengembangan hubungan dengan Influencer dan juga konsumer yang tertarik dengan bisnis tersebut di media sosial (Goyena, 2019).

\section{METODE}

\subsection{RESPONDEN PENELITIAN}

Penelitian yang kami lakukan akan didasari melalui survey kuesioner yang melibatkan sebanyak 385 orang yang ditujukan kepada masyarakat Kota Batam dengan jenjang usia 18 30 tahun keatas. Penelitian ini menggunakan metode sampling Random Proportional Cluster Sequence yang telah diperoleh dari hasil survey sementara melalui 36 responden pertama.

Penelitian yang kami lakukan melibatkan 5 Cluster / daerah, yakni : (1) Batam Centre sebanyak 150 orang per-cluster; (2) Sungai Panas sebanyak 72 orang per-cluster; (3) Nagoya sebanyak 65 orang per-cluster; (4) Baloi sebanyak 33 orang per-cluster; dan (5) Batu aji sebanyak 66 orang per-cluster.

\subsection{MODEL PENELITIAN}

Metode Penelitian ini memfokuskan pada fenomena yang digambarkan secara numerik, hal yang diukur berdasarkan besarnya sampel, cakupan berupa hipotesis atau pertanyaan spesifik melalui kuesioner, perhitungan validitas statistik secara akurat yang merefleksikan populasi tersebut dan pemahaman atas pikiran / perasaan responden terhadap topik penelitian yang kami lakukan.

Temuan penelitian dan wawasan teoritis dirangkum dalam model berikut. Model penelitian ini mengeksplorasi hubungan antara ikatan sebuah branding dengan dampak keterlibatan komunitas Influencer yang dilakukan dengan adanya potensi pengembangan ide kreativitas melalui sarana platform media sosial. 


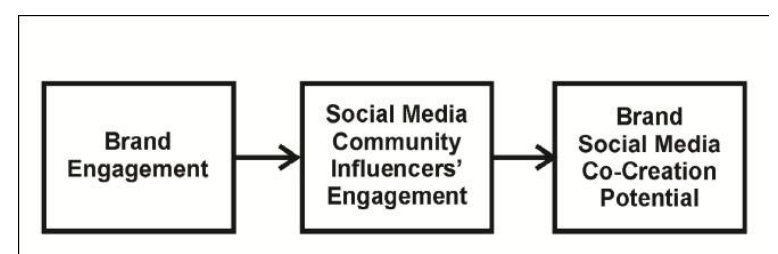

Figure 3. Causal Model

Dengan demikian, terdapat 4 hipotesis dalam penelitian ini, yaitu :

H1A : Ikatan / keterlibatan suksesnya sebuah branding dapat dipengaruhi oleh bantuan komunitas Influencers.

H10 : Ikatan / keterlibatan suksesnya sebuah branding tidak dapat dipengaruhi oleh bantuan komunitas Influencers.

H2A : Komunitas Influencer dapat mempengaruhi suksesnya sebuah branding melalui bantuan kreativitas sosial media.

H2O : Komunitas Influencer tidak dapat mempengaruhi suksesnya sebuah branding melalui bantuan kreativitas sosial media.

\subsection{INSTRUMEN PENELITIAN}

Penelitian ini mencakup 3 jenis variabel data sebagai tolak ukur dari survey yang akan dilakukan. Jenis Variabel tersebut yaitu : Independent Variable, Mediating Variable dan Dependent Variable. Responden akan diminta untuk mengisi kuesioner berupa pendapat mereka terhadap hubungan variabel tersebut atau opini terhadap pengaruh platform media sosial terhadap kesuksesan branding melalui bantuan komunitas Influencers.

1) Independent Variable pada penelitian ini merupakan variabel Brand Engagement yang akan mengukur jumlah iklan yang diunggah perharinya di jaringan media sosial (pada penelitian ini kami mengkhususkan platform Instagram) melalui akun pengguna. Variabel ini memiliki dimensi berupa konektivitas, kepercayaan dan hubungan kolaboratif antara Influencer dan Produsen.

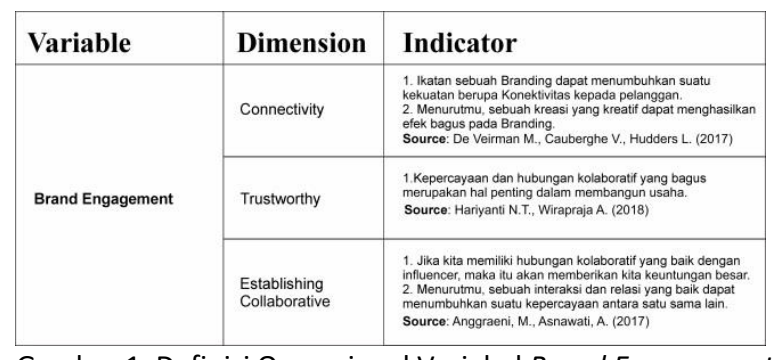

Gambar 1. Definisi Operasional Variabel Brand Engagement

2) Mediating Variable pada penelitian ini merupakan variabel Social Media Community Influencers' Engagement yang akan diukur berdasarkan jumlah respon / balasan dan jumlah mention terhadap produk yang dipromosikan melalui akun Influencer. Balasan dan Mention adalah tipe khusus pada Instagram yang dapat membangun pemikiran dan pendapat antara konsumer dan produsen. Variabel ini memiliki dimensi berupa Relevansi / penepatan Influencer yang dipilih, ekspektasi terhadap peningkatan produk dan tingkat kepuasan produsen terhadap jasa tersebut.

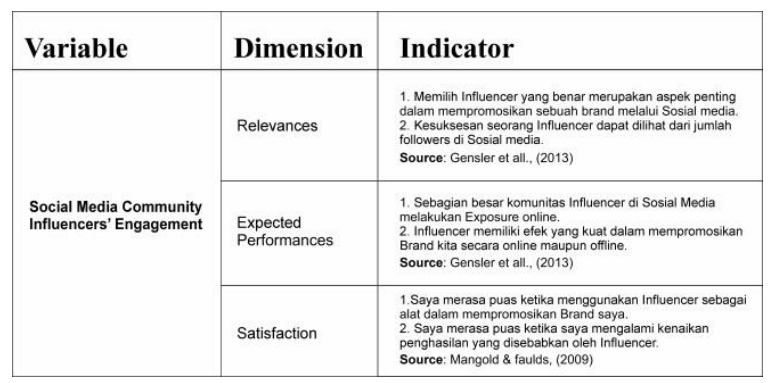

Gambar 2. Definisi Operasional Variabel Social Media Community Influencers' Engagement.

3) Dependent Variable pada penelitian ini merupakan variabel Co-creation Potential in Social Media Environment yang diukur berdasarkan hasil dari kreativitas / ide terhadap target produk, pengembangan produk perharinya setelah dipromosikan melalui Influencer di platform media sosial. Variabel ini memiliki dimensi berupa partisipasi produsen terhadap brand dan aspek penting yang harus dimiliki oleh prosuden terhadap brand tersebut.

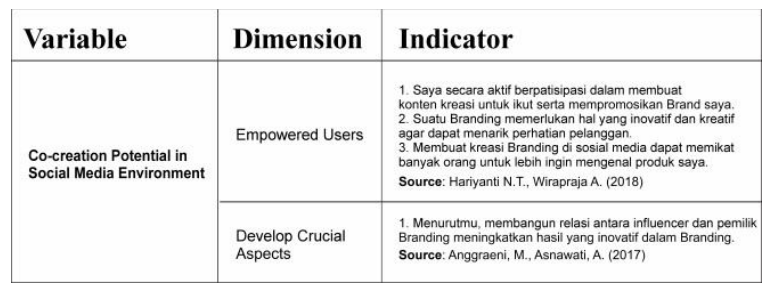

Gambar 3. Definisi Operasional Variabel Co-creation Potential in Social Media Environment. 


\subsection{UJI PENELITIAN}

Hasil penelitian akan dianalisis dari 2 sisi, yakni : (1) Membandingkan hasil dari penjualan / jumlah produk yang terjual pada kondisi sebelum dan sesudah melakukan endorse terhadap jasa Influencers di media sosial; dan (2) melihat seberapa besar pengaruh yang didapatkan produsen terhadap jasa endorse terhadap produk yang dipromosikan oleh Influencers melalui platform media sosial.

Jawaban responden kemudian akan diuji secara regresi linear sederhana yang terdiri dari 4 asumsi, yakni : 1) Asumsi Linearitas, apakah variabel mempunyai hubungan yang linear atau tidak secara signifikan; 2) Asumsi Normalitas, apakah nilai residual terdistribusi normal atau tidak; 3) Asumsi Homoskedastisitas, kondisi ketika nilai residu pada tiap nilai prediksi bervariasi dan variasinya cenderung konstan; dan 4) Asumsi Autokorelasi, untuk melihat apakah terjadi korelasi antara suatu periode $t$ dengan periode sebelumnya ( $t-1)$. Pengujian ini juga akan melakukan pembuktian asumsi klasik. (Pengujiannya dijelaskan pada week berikutnya sir).

\section{HASIL PENELITIAN}

Hasil ini memuat pernyataan singkat mengenai topik yang telah kami teliti. Berikut merupakan deskriptif diagram dan besar persentase dari hasil survey responden :

1. Persebaran Jenis Kelamin

Hasil survey menunjukkan bahwa persentase Masyarakat ber-jenis kelamin Wanita mendominasi sebesar 50.6\%, sedangkan persentase Masyarakat ber-jenis kelamin Pria sebesar $49.4 \%$.

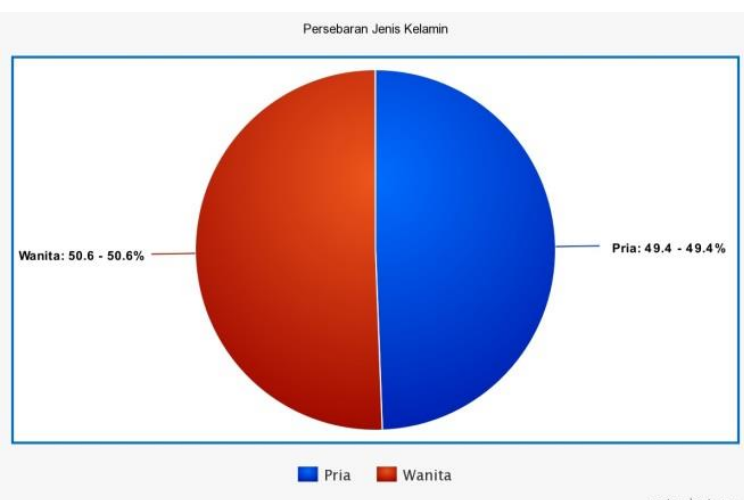

Gambar 1. Hasil Persentase Persebaran Jenis Kelamin

\section{Persebaran Lokasi Daerah / Cluster}

Hasil Survey menunjukkan bahwa persentase daerah Batam Centre mencapai sebesar 39.4\%, daerah Sungai Panas sebesar $17.6 \%$, daerah Nagoya sebesar $17.6 \%$, daerah Batu Aji sebesar $13.8 \%$ dan daerah Baloi sebesar $11 \%$.

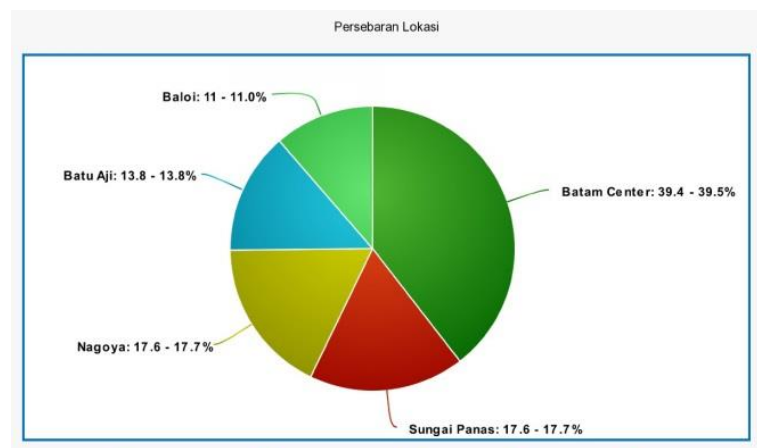

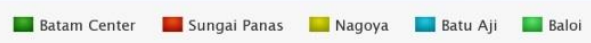

Gambar 2. Hasil Persentase Persebaran Lokasi Daerah atau Cluster.

\section{Persebaran Umur}

Hasil survey menunjukkan bahwa dalam keterlibatan pengisian survey penelitian, persentase jenjang usia 23-26 tahun paling mendominasi yaitu sebesar $44.8 \%$, sedangkan usia $27-31$ tahun yaitu sebesar $28.4 \%$, usia $18-22$ tahun sebesar $20.5 \%$ dan usia 32 tahun keatas sebesar $6.4 \%$.

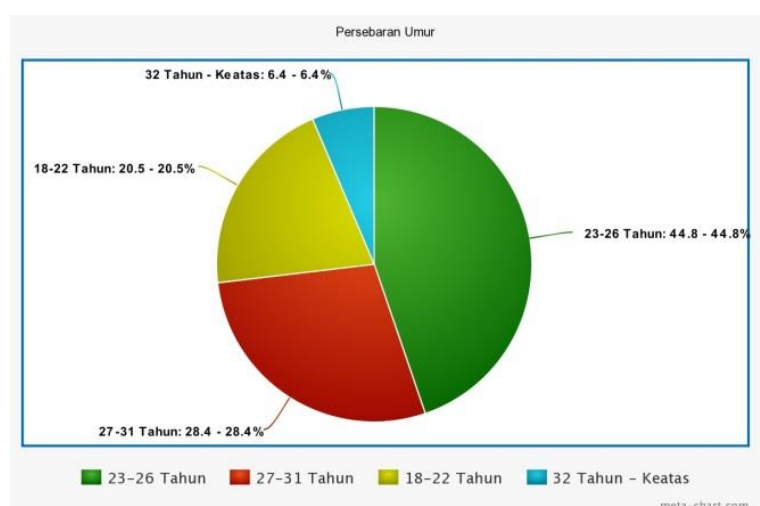


Gambar 3. Hasil Persentase Persebaran Umur.

Dengan demikian kami telah memperoleh hasil uji data yang terdeteksi outlier sebanyak 36 data dari total 428 data pada penelitian ini. Uji Validitas Data yang kami lakukan yaitu menggunakan Pearson Correlation dan menunjukkan bahwa pertanyaan itu adalah Valid. Uji Reliabilitas pada penelitian ini menggunakan Cronbach's Alpha dan semuanya berada di atas angka 0.6, sehingga dapat diasumsikan konstruk penelitian tersebut adalah Reliable. Selanjutnya, hasil dari Uji R Square diperoleh sebesar 0.596 dan uji $F$ sebesar 286.692, hal ini menandakan bahwa secara umum model tersebut cocok pada fenomena yang ada pada penelitian ini. Uji data ini juga memperoleh nilai Durbin Watson yaitu sebesar 1.902. Penggunaan nilai ini bertujuan untuk menguji apakah ada atau tidak autokorelasi. Dasar pengambilan keputusannya yaitu jika nilai Durbin-Watson berada pada rentang -2 $\leq$ Durbin-Watson $\leq 2$, maka tidak terjadi autokorelasi. Sedangkan jika tidak pada rentang tersebut, terjadi autokorelasi. Karena pada kasus ini dihasilkan nilai 1.902 yang berada pada rentang $-2 \leq n \leq 2$, maka antara variabel branding dan komunitas Influencer tidak terjadi autokorelasi.

Selanjutnya, mengenai uji Hipotesi pada penelitian ini, kami mendapatkan bahwa angka korelasi pada variable Branding terdapat konstanta senilai 0.557 dengan signifikansi Sig. = $0.000<0.05$ yang artinya $\mathrm{H} 1 \mathrm{~A}$ diterima dan $\mathrm{H} 10$ ditolak. Variabel branding berpengaruh secara signifikan yaitu dengan ditunjukkan bahwa ikatan / keterlibatan suksesnya sebuah branding sangat dipengaruhi oleh bantuan komunitas Influencers. Penelitian ini juga mendapatkan bahwa angka korelasi antara variabel media sosial dan komunitas Influencer terdapat konstanta senilai 0.326 dengan signifikansi Sig. $=$ $0.001<0.05$, yang artinya $\mathrm{H} 2 \mathrm{~A}$ diterima dan $\mathrm{H} 20$ ditolak. Hal ini menunjukkan bahwa hubungan keduanya berpengaruh signifikan. Komunitas Influencer tentu dapat mempengaruhi suksesnya sebuah branding melalui ide kreativitas di platform sosial media.

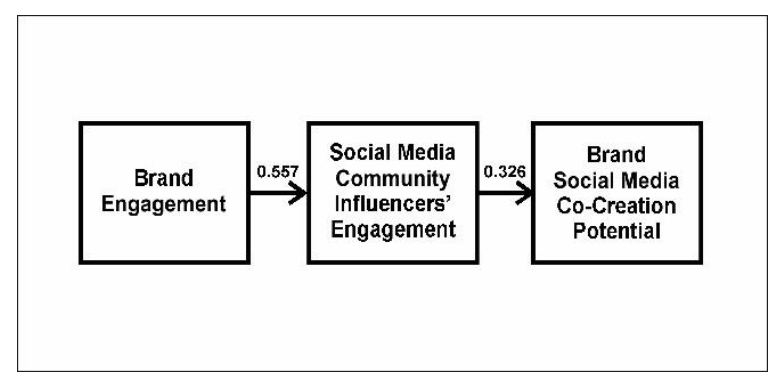

Gambar 4. Hasil Akhir Uji Penelitian pada Model Hipotesis

\section{KESIMPULAN \& PEMBAHASAN}

Penelitian ini mengarah kepada kesimpulan bahwa lingkungan media sosial menjadi kunci elemen revolusioner dari Internet dalam praktik pemasaran branding secara modern. Lingkungan sosial yang dinamis antara konsumen dan produsen saling terhubung dan terlibat dalam jaringan informasi dan distribusi sehingga pengguna mampu melihat lebih dari satu perspektif terhadap nilai-nilai bisnis. Hal ini menjadi inti masalah bahwa pemasar harus mencurahkan perhatian strategis terhadap fenomena masa kini untuk dapat menarik perhatian konsumer dengan cara memanfaatkan platform media sosial sebagai sarana pemasaran branding yang akan dilakukan oleh komunitas Influencers. Melalui hasil analisis regresi dan spss, penelitian ini menyatakan bahwa hubungan atau keterkaitan antara ketiga variabel tersebut yakni ikatan branding, sosial media dan komunitas Influencer, menunjukkan adanya pengaruh yang cukup signifikan terhadap dampak peningkatan produk yang dihasilkan oleh produsen melalui jasa komunitas Influencer di sosial media.

Penelitian ini dijelaskan dengan hasil perhitungan determinasi R square sebesar $59,6 \%$ yang berarti bahwa variabel media sosial memiliki hubungan dan pengaruh dari variabel bebas X1 dan X2 (branding dan influencer) dan sisa sebesar $40.4 \%$ dipengaruhi oleh variabel lain yang belum terdapat pada model penelitian ini. Hal tersebut dapat dipercaya oleh masyarakat sebagai hal yang menjadi acuan sumber informasi mengenai berbagai produk yang dipasarkan dan layanan komunikasi yang dilakukan dalam sosial media. Hasil penelitian ini mencakup kesimpulan bahwa media sosial menjadi fokus yang kuat untuk mengembangkan 
branding yang dilibatkan dari kerja sama antar produsen dan komunitas influencer dalam menentukan potensi tingkat penjualan aktual perusahaan.

Dalam penelitian ini kami juga mendapatkan hasil diskusi dari nilai persamaan yang dihasilkan oleh uji regresi. Telah diperoleh persamaan sebagai berikut : Media Sosial $=(0.563)+(0.557$ $*$ Branding $)+(0.326 *$ Influencer $)$ sehingga memperoleh total hasil konstanta senilai 4.978. Nilai konstanta pada variabel dependen (media sosial) terdapat sebesar 0.563 yang menyatakan bahwa jika kedua variabel bebas yaitu nilai pada variabel Branding (X1) dan Influencer (X2) konstan (tetap), maka nilai variabel media sosial (Y) meningkat sebesar 0.563. Angka tersebut didapatkan dalam bentuk standardized dari persamaan regresi melalui uji spss dan cocok pada fenomena ini. Nilai tersebut terbilang memiliki instrumen yang cukup tinggi, yang artinya responden setuju bahwa secara skala kecil maupun besar, kesuksesan sebuah Branding memang dapat secara konstan dipengaruhi oleh lingkungan sosial media jika produsen juga dapat memilih seorang Influencer yang tepat. Hal tersebut dikenal dengan istilah "Wisdom of Crowd" yang artinya keterlibatan masyarakat / user dan Influencer di dalam sosial media dapat membentuk sebuah pasar di dunia maya secara terus menerus dalam kurun waktu cepat.

Persamaan regresi tersebut juga menunjukkan nilai koefisien variabel branding (X1) sebesar 0.557 yang berarti jika pemasaran branding suatu perusahaan meningkat satu satuan maka pemasaran yang digunakan melalui jasa komunitas Influencer akan meningkat 0.557 satuan. Angka tersebut didapatkan karena asumsi masyarakat / responden pada penelitian ini percaya bahwa suksesnya sebuah branding memang secara signifikan dapat dipengaruhi oleh komunitas Influencer. Seperti dari hasil wawancara yang telah kami lakukan dari salah satu Influencer terkenal di Kota Batam, yaitu Batamliciouz yang bergerak di bidang Kulineran, ia sendiri mengatakan bahwa komunitas Influencer sendiri dikenal dengan istilah "Large Social Network" yang artinya semakin besar suatu jaringan sosial yang disebarkan, semakin cepat juga efek yang diberikan terhadap branding tersebut. Influencer sendiri tugasnya adalah untuk "mempengaruhi" dan memberikan review atau rekomendasi produk kepada jaringan pengikut / followersnya sehingga produk yang dipasarkan dapat mengalami peningkatan secara signifikan dan lebih dikenal orang secara luas. Batamliciouz juga mengatakan bahwa "Branding is not free, but Social Media is free", yang berartikan bahwa branding memang membutuhkan modal uang yang cukup untuk dapat menggunakan jasa Influencer sebagai perantara promosi brand kepada publik.

Selanjutnya, persamaan regresi tersebut juga menunjukkan bahwa nilai koefisien variabel Influencer di sosial media (X2) sebesar 0.326 yang berarti apabila strategi promosi melalui Influencer di media sosial meningkat satu satuan, maka pemasaran dari Influencer yang digunakan melalui platform media sosial akan meningkat 0.326 satuan. Nilai ini didapatkan dari hasil uji menggunakan spss yang berarti masyarakat meyakini bahwa posisi popularitas dari sosial media pun turut mempengaruhi tingkat popularitas dari seorang Influencer dan memperbanyak jumlah Influencer dalam platform tersebut. Secara tidak langsung, responden percaya bahwa hal itu tentu akan menjangkau tingkat konsumen yang lebih luas dalam penggunaan platform media sosial. Hal ini juga dijelaskan dari penelitian data sebelumnya yang diluncurkan oleh Tetra Pak Index tahun 2019, mencatatkan ada sekitar 132 juta lebih pengguna internet di Indonesia dan setengahnya adalah penggila media sosial, atau berkisar di angka 55\%, dimana angka ini mengalami kenaikan dari tahun 2020 yaitu sebesar $60 \%$. Terkait dengan hal itu, responden setuju bahwa hubungan yang terjadi dalam konteks tersebut semuanya berkaitan.

Masyarakat juga percaya bahwa sebagian besar Influencer yang muncul saat ini memang bukan berasal dari kalangan artis, melainkan mereka diciptakan dari platform media sosial itu sendiri yang menjadikan para public figure tersebut lebih dikenal orang / pengguna media sosial di semua kalangan melalui karya atau ide kreativitas yang Influencer lakukan di sosial media. Istilah "Electronic Word of Mouth" di era inilah segala yang dipasarkan melalui media sosial tentu akan sangat berpengaruh pada aktual penjualan usaha. Tidak heran dalam uji 
penelitian ini banyak masyarakat yang setuju dan sadar bahwa dampak yang ditimbulkan oleh media sosial memang dapat menciptakan jumlah peningkatan dari segi tingkat penjualan,

\section{DAFTAR PUSTAKA}

1. Cakranegara, P. A. (2017). Analisis Strategi Implementasi Media Sosial. Perusahaan Studi Manajemen, 1-16.

2. Chandy, R. (2010). Consumer Cocreation in New Product Development. Journal of Service Research, 283.

3. Cheng, C. \&. (2015). The Influence of Destination Personality on Brand Image Evaluation among Archaeological Tourists. Jurnal Komunikasi, Malaysian Journal of Communication, 152.

4. Goyena, R. (2019). Strategi Pemasaran Branding. Journal of Chemical Information and Modeling, 1699.

5. Gunantara, N. (2015). Performansi WLAN dan Area Blank Spot pada Pusat Kabupaten Badung. Journal of Teknologi Elektro, 14(2), 34-38.

6. Hanski. (2015). New Business Set Up for Branding Strategies . Procedia Computer Science, 23.

7. Hoyer, W. D. (2010). Consumer Cocreation in New Product Development. Journal of Service Research, 283.

8. Igors, S. (2014). Brand Equity and CoCreation Potential in the Social Media Environment : An Analysis of Brand Engagement with Community Influencers. Journal of Management and Governance., 16.

9. Jansen, B., Zhang, M., Sobel, K., \& Chowdury, A. (2009). Electronic Word of Mouth. Journal of the American Society for Information Science and Technology, 2168. pemakaian platform maupun jumlah Influencer pada komunitasnya.

10. Kärkkäinen, Jussila, \& Väisänen. (2010). The Role of Social Media B2B Relationship Marketing. Journal of Third Malaysian, 322.

11. Karunakaran, K. P. (2018). Pengaruh Testimoni dan Selebgram Endorsement. Journal of Materials Processing Technology, 8.

12. Naaman, M., Boase, J., \& Lai, C. (2010). Message Content in Social Awareness Streams. Proceedings of the ACM Conference on Computer Supported Cooperative Work, CSCW, 192.

13. Ashi, C. (2012). Customer Engagement, Buyer-Seller Relationships and Social Media. Management Decision, 252.

14. Suri, M. (2017). The Influence of Celebrity Endorser Online Shop on Instagram to Company Image Ladyfame Shop. Jurnal IImu Sosial dan Komunikasi, 92. 